\title{
Spectral dependence of aerosol light absorption over the Amazon Basin
}

\author{
L. V. Rizzo ${ }^{1}$, A. L. Correia $^{2}$, P. Artaxo ${ }^{2}$, A. S. Procópio ${ }^{3}$, and M. O. Andreae \\ ${ }^{1}$ Institute of Environmental, Chemical and Pharmaceutics Sciences, Department of Earth and Exact Sciences, Federal \\ University of São Paulo, Brazil \\ ${ }^{2}$ Institute of Physics, University of São Paulo, Brazil \\ ${ }^{3}$ Department of Sanitary and Environmental Engineering, Federal University of Juiz de Fora, Brazil \\ ${ }^{4}$ Max Planck Institute for Chemistry, Biogeochemistry Department, Mainz, Germany
}

Received: 31 March 2011 - Published in Atmos. Chem. Phys. Discuss.: 13 April 2011

Revised: 21 July 2011 - Accepted: 21 August 2011 - Published: 1 September 2011

\begin{abstract}
In this study, we examine the spectral dependence of aerosol absorption at different sites and seasons in the Amazon Basin. The analysis is based on measurements performed during three intensive field experiments at a pasture site (Fazenda Nossa Senhora, Rondônia) and at a primary forest site (Cuieiras Reserve, Amazonas), from 1999 to 2004. Aerosol absorption spectra were measured using two Aethalometers: a 7-wavelength Aethalometer (AE30) that covers the visible (VIS) to near-infrared (NIR) spectral range, and a 2-wavelength Aethalometer (AE20) that measures absorption in the UV and in the NIR. As a consequence of biomass burning emissions, about 10 times greater absorption values were observed in the dry season in comparison to the wet season. Power law expressions were fitted to the measurements in order to derive the absorption Ångström exponent, defined as the negative slope of absorption versus wavelength in a log-log plot. At the pasture site, about $70 \%$ of the absorption Ångström exponents fell between 1.5 and 2.5 during the dry season, indicating that biomass burning aerosols have a stronger spectral dependence than soot carbon particles. Ångström exponents decreased from the dry to the wet season, in agreement with the shift from biomass burning aerosols, predominant in the fine mode, to biogenic and dust aerosols, predominant in the coarse mode. The lowest absorption Ångström exponents (90\% of data below 1.5) were observed at the forest site during the dry season. Also, results indicate that low absorption coefficients were associated with low Ångström exponents. This finding suggests
\end{abstract}

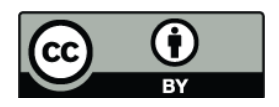

Correspondence to: L. V. Rizzo (luvarizzo@gmail.com) that biogenic aerosols from Amazonia have a weaker spectral dependence for absorption than biomass burning aerosols, contradicting our expectations of biogenic particles behaving as brown carbon. In a first order assessment, results indicate a small $(<1 \%)$ effect of variations in absorption Ångström exponents on 24-h aerosol forcings, at least in the spectral range of $450-880 \mathrm{~nm}$. Further studies should be taken to assess the corresponding impact in the UV spectral range. The assumption that soot spectral properties represent all ambient light absorbing particles may cause a misjudgment of absorption towards the UV, especially in remote areas. Therefore, it is recommended to measure aerosol absorption at several wavelengths to accurately assess the impact of non-soot aerosols on climate and on photochemical atmospheric processes.

\section{Introduction}

Aerosols directly influence the Earth's energy budget by scattering and absorbing solar radiation. Aerosol light absorption affects the atmosphere by reducing the radiation reaching the surface. Furthermore, it can influence the tropospheric temperature structure, which in turn may have an effect on cloud formation, a phenomenon that has been called the semi-direct effect (Hansen et al., 1997). Also, aerosol absorption in the UV may affect atmospheric photolysis rates, influencing, for example, ozone concentrations in the troposphere (Albuquerque et al., 2005; Jacobson, 1999). In spite of the efforts to improve measurements and datasets over recent years, large uncertainties remain in the current estimates of aerosol

Published by Copernicus Publications on behalf of the European Geosciences Union. 
forcing on climate, in part due to incomplete knowledge of aerosol absorption properties (Yu et al., 2006; IPCC, 2007).

Several studies have shown that the aerosol absorption coefficient decreases monotonically with wavelength (e.g., Bergstrom et al., 2007). It is usual to approximate this wavelength dependence by a power-law expression, taking the logarithm of absorption as a function of the logarithm of the wavelength. Often, a "linear" fit to this log-log curve is a good approximation:

$\ln \left[\frac{\sigma_{\mathrm{abs}}(\lambda)}{\mathrm{Mm}^{-1}}\right]=\ln (b)-\stackrel{\circ}{a}_{\mathrm{abs}} \ln \left[\frac{\lambda}{\mathrm{nm}}\right]$,

where $\sigma_{\mathrm{abs}}(\lambda)$ is the absorption coefficient measured at the wavelength $\lambda, \stackrel{\circ}{a b s}_{\text {abs }}$ is known as the absorption Ångström exponent, and $b$ is known as the turbidity coefficient (Schuster et al., 2006). According to the original formulation by Ångström (1929), the fitting parameter $\stackrel{\leftrightarrow}{a}_{\text {abs }}$ does not depend on wavelength. However, in some cases $\stackrel{\leftrightarrow}{a b s}_{\text {abs }}$ shows a significant variation depending on the selected spectral range, requiring the application of a "quadratic" fit:

$\ln \left[\frac{\sigma_{\mathrm{abs}}(\lambda)}{\mathrm{Mm}^{-1}}\right]=\ln (b)-\stackrel{\circ}{\mathrm{abs}}_{\mathrm{a}} \ln \left[\frac{\lambda}{\mathrm{nm}}\right]+c \ln ^{2}\left[\frac{\lambda}{\mathrm{nm}}\right]$,

in which $c$ is known as the curvature term (Schuster et al., 2006). Alternatively, it is possible to assess the variability of $\stackrel{\circ}{a}_{\text {abs }}$ by calculating its value from neighboring spectrum points $\left(\sigma_{\mathrm{abs}}\left(\lambda_{1}\right) ; \sigma_{\mathrm{abs}}\left(\lambda_{2}\right)\right)$ all across the measured spectral range:

$\stackrel{\circ}{a b s}_{a}=-\frac{\ln \left(\frac{\sigma_{\mathrm{abs}}\left(\lambda_{1}\right)}{\sigma_{\mathrm{abs}}\left(\lambda_{2}\right)}\right)}{\ln \left(\frac{\lambda_{1}}{\lambda_{2}}\right)}$.

The spectral dependence of absorption relies on aerosol physical and chemical properties. The major light-absorbing components of aerosols are carbonaceous substances and mineral dust. According to Andreae and Gelencsér (2006), soot carbon particles, formed during combustion processes, consist of aggregates of spherules made of graphene layers, being almost purely carbon. Due to its morphology and relatively constant refractive index, the absorption spectrum of soot carbon is expected to exhibit Ångström exponents of about $1.0 \pm 0.1$ for particles with diameters in the range 10$100 \mathrm{~nm}$ (Sun et al., 2007; Gyawali et al., 2009). Measurements taken at urban areas support this statement (e.g., Marley et al., 2009; Bond and Bergstrom, 2006; Schnaiter et al., 2003). Besides soot, there are other kinds of light-absorbing carbonaceous aerosols in the atmosphere, originated either from low temperature combustion or from processes like oxidation of biogenic materials and polymerization (Andreae and Crutzen, 1997). These light absorbing particles are often denominated "brown carbon", and include soil humics, humic-like substances and biogenic aerosols, among others (Andreae and Gelencsér, 2006; Sun et al., 2007). The absorption cross section of non-soot carbon increases very sharply with decreasing wavelength, resulting in Ångström exponents significantly greater than unity. Ångström exponents greater than 1.5 have also been observed in dust aerosol (Bergstrom et al., 2007; Alexander et al., 2008). Ångström exponents for mixed aerosols originated from combustion of lignite, hard coal and biomass range from 1.0 to 2.5 (Kirchstetter 2004). Studies indicate that, if soot particles were removed from these samples, the Ångström exponent for the remaining material would be greater than 2.5 (Sun et al., 2007). In accordance with that, Hoffer et al. (2006) obtained absorption Ångström exponents in the range of 6.0-7.0 for humic-like substances (HULIS) isolated from the fine fraction of biomass burning aerosols in Amazonia.

The different spectral dependence of absorption by soot carbon and other light absorbing aerosols implies that caution should be taken when extrapolating absorption measured at one single wavelength over the entire solar spectrum. The assumption that soot spectral properties represent all ambient light absorbing particles may underestimate the absorption of UV radiation, especially when the mass concentration of soot is relatively low in comparison to that of brown carbon and dust. Therefore, it is important to describe accurately the spectral dependence of representative types of ambient aerosols to assess the impact of light absorbing particles on the Earth's energy budget.

This paper presents a systematic analysis of aerosol absorption spectra measured during three different field campaigns in Amazonia. It provides a general description of the wavelength dependence of absorption both during the Amazonian wet season, when the aerosol population is dominated by biogenic particles, comprising primary and secondary aerosols of biological origin (Fuzzi et al., 2006), and during the dry season, when there is a dominant influence of biomass burning emissions. It is important to describe accurately the optical behavior of these particles in order to assess the impact of anthropogenic changes on the regional climate. Since the Amazon forest is located in a region of intense convective activity, the aerosols released there can be long-range transported, potentially resulting in climate effects that are globally relevant (Ramanathan and Carmichael, 2008; Freitas et al., 2005; Andreae et al., 2001).

\section{Materials and methods}

\subsection{Field experiments}

This study is based on measurements taken during three intensive field experiments at two Amazonian sites, from 1999 to 2004. The pasture site (Fazenda Nossa Senhora, Rondônia State, Brazil) is located in the southwestern margin of the Amazon Basin, in an area under the influence of vegetation fire emissions during the dry season. The forest site (Cuieiras Reserve, Amazonas State, Brazil) is in a nature preserve, but occasionally receives the influence of regional biomass 


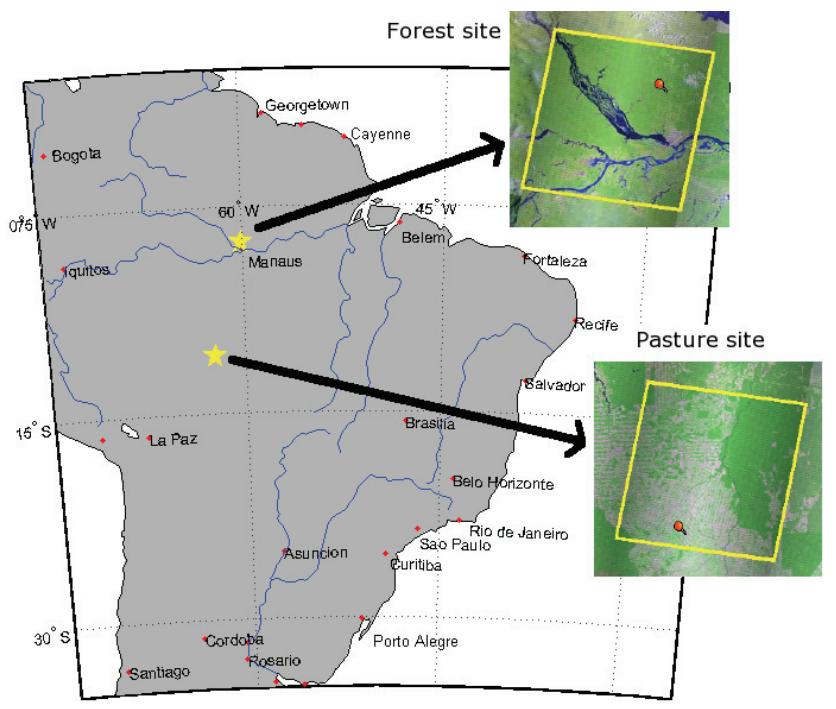

Fig. 1. Diagram showing the locations of the two Amazonian sampling sites considered in this study. Satellite data available from the US Geological Survey.

burning pollution during the dry season (Fig. 1). All experiments were taken under the scope of the LBA project (Large-scale Biosphere-Atmosphere experiment in Amazonia) (Avissar et al., 2002; Davidson and Artaxo, 2004). Measurement conditions during each field experiment are briefly described below.

1. Pasture Dry 1999 - LBA/EUSTACH (European Studies on Trace gases and Atmospheric Chemistry): this intensive field experiment was conducted at a pasture site (Fazenda Nossa Senhora - FNS, $10^{\circ} 45.73^{\prime} \mathrm{S}, 62^{\circ}$ $21.45^{\prime} \mathrm{W}, 315 \mathrm{~m}$ a.s.1.) in Western Amazonia, from 17 September to 26 October 1999. During the whole experiment, the site was heavily affected by biomass burning emissions. Aerosol attenuation was measured at a height of $2 \mathrm{~m}$, using a 7-wavelength Aethalometer (AE30) $(\lambda=450,571,590,615,660,880$, and $950 \mathrm{~nm})$. The $571 \mathrm{~nm}$ channel was not included in the analysis due to its systematically low signal. The Aethalometer was operated under ambient conditions with a $10 \mu \mathrm{m}$ cut-off diameter. More details about this field experiment can be found in Andreae et al. (2002) or Artaxo et al. (2002).

2. Pasture Dry to Wet 2002 - LBA/SMOCC (Smoke, Aerosols, Clouds, Rainfall and Climate): the groundbased component of this intensive field experiment was conducted at the FNS pasture site from 5 September to 14 November 2002. Three periods can be distinguished: the dry period heavily influenced by biomass burning events (5 September-7 October); a transition period in which the biomass burning signature was significantly reduced (8-30 October); and the wet period when the aerosol concentration reached its lowest levels (31 October-14 November) (Fuzzi et al., 2007). Aerosol attenuation was measured at a height of $2 \mathrm{~m}$, using a 7-wavelength Aethalometer (AE-30) $(\lambda=450$, $571,590,615,660,880$, and $950 \mathrm{~nm})$. The $571-\mathrm{nm}$ and $590-\mathrm{nm}$ channels were not included in the analysis due to systematically low signals. The Aethalometer was operated under ambient conditions with a $10 \mu \mathrm{m}$ cut-off diameter. More details about this field experiment can be found in Andreae et al. (2004).

3. Forest Dry 2004 - LBA/ZF2-C14 Tower: this intensive field experiment was conducted at a forest site, Reserva do Cuieiras, located about $60 \mathrm{~km} \mathrm{NNW}$ of Manaus. The experiment ran during the dry season, from 13 August to 1 October 2004 at the $\mathrm{C} 14$ tower $\left(2^{\circ} 35.35^{\prime} \mathrm{S}, 60^{\circ}\right.$ $06.89^{\prime} \mathrm{W}, 140 \mathrm{~m}$ a.s.1.), located at $\mathrm{km} 14$ of the ZF2 access road in the Cuieiras ecological reserve. The site is undisturbed by local biomass burning emissions. Nevertheless, during the dry season the site suffers the influence of biomass burning emissions through regional transport of air masses. Aerosol attenuation was measured above the canopy top (about $28 \mathrm{~m}$ ), at a height of $40 \mathrm{~m}$, using a 2-wavelength Aethalometer (AE-20) $(370,880 \mathrm{~nm})$. The Aethalometer was operated under ambient conditions with a $10 \mu \mathrm{m}$ cut-off diameter. More details about this field experiment can be found in Rizzo et al. (2010).

\subsection{Aerosol attenuation measurements}

Aethalometers measure the light attenuation through a quartz filter matrix as aerosols are deposited. The attenuation coefficient $\left(\sigma_{\mathrm{ATN}}\right)$ is given by

$\sigma_{\mathrm{ATN}}=\frac{A_{f}}{Q} \frac{\Delta \mathrm{ATN}}{\Delta t}$,

where $A_{f}$ is the filter spot area, $Q$ the volumetric flow rate, and $\triangle \mathrm{ATN}$ is the change in attenuation during the time interval $\Delta t$. The standard output of the manufacturer provides equivalent black carbon mass concentration $\mathrm{BC}_{\mathrm{ATN}}$ (ng $\mathrm{m}^{-3}$ ), which is calculated from $\sigma_{\mathrm{ATN}}$ according to

$\mathrm{BC}_{\mathrm{ATN}}=\frac{\sigma_{\mathrm{ATN}}}{\alpha_{\mathrm{ATN}}}$,

where

$\alpha_{\mathrm{ATN}}\left[\mathrm{m}^{2} \mathrm{~g}^{-1}\right]=\frac{14625}{\lambda[\mathrm{nm}]}$

is the spectral mass-specific attenuation cross-section based on a calibration using a solvent-based thermal desorption method for elemental carbon analysis. Aiming to minimize uncertainties (Schmid et al., 2001), the primary measurement parameter of the Aethalometer, $\sigma_{\mathrm{ATN}}$, will be investigated in this study. Therefore, all $\mathrm{BC}_{\mathrm{ATN}}$ values delivered by the manufacturer's data acquisition software were converted into $\sigma_{\text {ATN }}$ using Eqs. (4) to (6). 


\subsection{Inferring absorption coefficients from attenuation measurements}

Several studies report that the attenuation coefficient $\left(\sigma_{\mathrm{ATN}}\right)$ may differ significantly from the aerosol absorption coefficient, $\sigma_{\text {abs }}$ (e.g., Weingartner et al., 2003; Arnott et al., 2005; Schmid et al., 2006; Moosmüller et al., 2009; Müller et al., 2011). The need to deposit the aerosol on a filter substrate during the measurement results in artifacts related to multiple scattering effects within the filter matrix, as well as filter loading effects. Weingartner et al. (2003) proposed the following correction to obtain absorption coefficients from Aethalometer attenuation measurements:

$\sigma_{\mathrm{abs}}=\sigma_{\mathrm{ATN}} \frac{1}{C \cdot R(\mathrm{ATN})}$,

where $C(\geq 1)$ accounts for multiple light scattering effects within the filter and $R(\mathrm{ATN})(\leq 1)$ corrects for filter loading effects. Due to aerosol-filter interactions, Aethalometers require site-specific calibration factors. The filter loading correction depends on attenuation, directly measured by the Aethalometer, to account for the decrease in sensitivity as the filter gets loaded with particles, and can be calculated through an empirical relationship:

$R(\mathrm{ATN})=\left(\frac{1}{f}-1\right) \frac{\ln \mathrm{ATN}-\ln 10}{\ln 50-\ln 10}+1$.

The parameter $f$ is known as the shadowing factor, and depends on the type of the aerosol. Schmid et al. (2006) obtained $f=1.2$ through an intercomparison of Aethalometer and PAS (photoacoustic spectrometer) measurements during the LBA/SMOCC experiment. They report that the loading effect accounts for a maximum sensitivity reduction of about $20 \%$ at $532 \mathrm{~nm}$.

According to Schmid et al. (2006), the multiple scattering correction $(C)$ is by far the most important effect when inferring absorption coefficients from attenuation. Its average value for the SMOCC dry and transition periods was determined as $C_{532}=5.23 \pm 0.17$ at the reference wavelength of $532 \mathrm{~nm}$. For the wet season, it was impossible to obtain calibration factors, mainly due to the poor signal-to-noise ratio caused by low aerosol loadings. The spectral dependence of $C$ can be calculated using

$C(\lambda)=C^{*}(\lambda)+m_{\mathrm{s}}(\lambda) \frac{\omega_{0}(\lambda)}{1-\omega_{0}(\lambda)}$,

where $m_{\mathrm{S}}$ represents the fraction of the aerosol scattering coefficient that is erroneously interpreted as absorption, $C^{*}$ is the multiple scattering correction factor that includes the effects of aerosol scattering, $\omega_{0}$ is the aerosol single scattering albedo, and $\lambda$ is the wavelength in $\mathrm{nm}$. The parameters $m_{\mathrm{s}}$ and $C^{*}$ are provided by Arnott et al. (2005) for ammonium sulfate particles. We are not aware of other published works investigating the performance of Aethalometers specifically with regard to Amazonian aerosols that could provide us with better estimates for $m_{\mathrm{s}}$ and $C^{*}$. $\omega_{0}(\lambda)$ can be calculated assuming that the spectral dependence of aerosol scattering $\left(\sigma_{\text {scat }}\right)$ and absorption $\left(\sigma_{\text {abs }}\right)$ coefficients can be described by power-law relationships, with $\stackrel{\circ}{\text { scat }}_{\text {and }}$ an $\stackrel{a}{\text { abs }}_{\text {being the respec- }}$ be tive Ångstrom exponents:

$$
\begin{aligned}
& \omega_{0}(\lambda)=\frac{\sigma_{\text {scat }}}{\sigma_{\text {scat }}+\sigma_{\text {abs }}} \\
& =\frac{\omega_{0}\left(\lambda_{\text {ref }}\right) \cdot\left[\frac{\lambda}{\lambda_{\text {ref }}}\right]^{-\AA_{\text {scat }}}}{\omega_{0}\left(\lambda_{\text {ref }}\right) \cdot\left[\frac{\lambda}{\lambda_{\text {ref }}}\right]^{-\stackrel{a}{s}_{\text {scat }}}+\left[1-\omega_{0}\left(\lambda_{\text {ref }}\right)\right] \cdot\left[\frac{\lambda}{\lambda_{\text {ref }}}\right]^{-\stackrel{\circ}{a}_{\text {abs }}}}
\end{aligned}
$$

Therefore, the spectral dependence of the correction factor $C$ depends on the previous knowledge of $\omega_{0}$ at some reference wavelength, as well as on the spectral dependence of aerosol scattering $\left(\stackrel{\circ}{a}_{\text {scat }}\right)$ and absorption $\left(\stackrel{\circ}{a}_{\text {abs }}\right)$ itself. Unfortunately, aerosol scattering coefficients at multiple wavelengths were not measured during any of the three experiments analyzed here. Thus, for lack of better choices, average values will be used, following the procedure from Schmid et al. (2006). The errors associated with the use of averages instead of specific

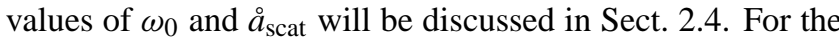
SMOCC experiment, Chand et al. (2006) reported average albedo values of $0.92 \pm 0.02$ at $545 \mathrm{~nm}$, and average scattering Ångstrom exponents of $2.0 \pm 0.4$. Using these average values, $C(\lambda)$ now depends only on $\stackrel{\leftrightarrow}{a}_{\text {abs }}$. This is an awkward situation, since $\stackrel{a}{a b s}_{\text {abs }}$ is actually what we want to determine, and it depends on itself. Schmid et al. (2006) solved this impasse by choosing a reasonable range of Ångstrom exponents for absorption $\left(\stackrel{\circ}{a}_{\mathrm{abs}}=1.0,1.5\right.$ and 2.0$)$ and parameterizing $C$ as a function of $\lambda$ and $\stackrel{a}{\text { abs }}$ : :

$C(\lambda)=C_{\mathrm{ref}} \cdot \frac{\lambda^{A \ln (\lambda / \mathrm{nm})+B}}{\lambda_{\mathrm{ref}}^{A \ln \left(\lambda_{\mathrm{ref}} / \mathrm{nm}\right)+B},}$

where $C_{\text {ref }}=C_{532}, \lambda_{\text {ref }}=532 \mathrm{~nm}$, and the coefficients $A$ and $B$ are expressed as a function of $\stackrel{a}{a b s}_{\text {ab }}$ :

$$
\begin{aligned}
& A=0.102 \cdot \stackrel{\circ}{\mathrm{abs}}_{\mathrm{a}}^{2}-0.187 \cdot \mathrm{a}_{\mathrm{abs}}-0.141 \\
& B=-1.275 \cdot \stackrel{a}{\mathrm{abs}}^{2}+2.564 \cdot \stackrel{\circ}{\mathrm{abs}}+1.827 \text {. }
\end{aligned}
$$

Using equations 11 and 12 it is possible to derive the spectral dependence of the multiple scattering correction factor as a function of $\stackrel{\circ}{a b s}_{\text {abs }}$, specifically for the SMOCC experiment conditions $\left(\omega_{0 \text { ref }}=0.92\right.$ and $\left.\stackrel{a}{\text { scat }}_{1}=2.0\right)$. However, since $\stackrel{a}{a b s}_{\text {abs }}$ is not known, an iterative procedure can be used, comprising the following steps:

1. As a first guess, use the spectral dependence of measured attenuation, i.e., the Ångstrom exponent for attenuation $\left(\stackrel{\circ}{\mathrm{ATN}}_{\mathrm{ATN}}\right)$, to calculate $C(\lambda)$ from Eqs. (11) and (12);

2. Determine absorption coefficients ( $\left.\sigma_{\text {abs }}\right)$ using Eqs. (7), (8) and (11);

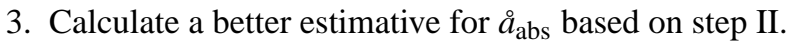


4. Repeat steps II and III until $\stackrel{\leftrightarrow}{a b s}_{\text {abs }}$ converges with a precision of 0.005 .

A similar procedure had been applied by Schmid et al. (2006) to their average attenuation spectrum. In the present work, the above procedure was applied for each measured attenuation spectrum, obtaining the best feasible deter-

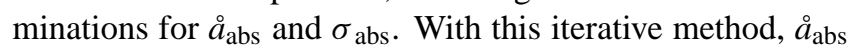
converged in less than 6 iterations for the dataset analyzed here. Overall, the corrected absorption coefficients at $450 \mathrm{~nm}$ were approximately $75 \%$ lower than the corresponding raw attenuation coefficients. Ångstrom exponents for absorption were roughly $40 \%$ greater than the corresponding Ångstrom exponents for attenuation. For comparison, Collaud Coen et al. (2010) found multiple scattering correction constants (C) ranging between 2.8 and 7.8 at $660 \mathrm{~nm}$ for several sites, measurement conditions, and correction procedures. In this work, $C$ averaged $5.72 \pm 0.14$ at $660 \mathrm{~nm}$.

Schmid et al. (2006) concluded that there was no significant variation of the Aethalometer correction factors between the sampling periods of the SMOCC experiment (dry and transition). For lack of a better alternative, they recommended to apply the correction factors derived for the SMOCC dry and transition periods also to the data of the SMOCC wet period. Going even further than that, we applied the parameters $A$ and $B$ (Eq. 9) and the calibration factor $C_{532}$ derived specifically for the SMOCC data to another two experiments conducted in Amazonia: LBA/EUSTACH and LBA/ZF2-C14 (Sect. 2.1). The application of the SMOCC correction parameters to the LBA/EUSTACH data is reasonable, since the experiment was carried out at the same pasture site and same season. The main reason for applying the same correction parameters to the LBA/ZF2-C14 experiment, carried out at a forest site during the dry season, is the absence of reference absorption measurements, as well as of site-specific estimates of $\omega_{0}$ and $\stackrel{\circ}{\text { scat }}_{\text {s. The errors asso- }}$ ciated to an imprecise choice of $\omega_{0}$ and $\stackrel{a}{\text { scat }}_{\text {sere evaluated }}$ through sensitivity tests, to be discussed in the next section.

Recent works indicate that the multiple scattering correction depends on particle size, because it varies with the aerosol penetration depth into the filter. Nakayama et al. (2010) compared filter based absorption measurements of nigrosin dye generated particles to predictions from Mie theory, and found increased sensitivities with decreasing diameters, leading to overestimations as high as $100 \%$ for $100 \mathrm{~nm}$ aerosols in diameter. On the other hand, Lack et al. (2009) reported underestimations of $50 \%$ for absorbing polystyrene spheres of $500 \mathrm{~nm}$, through the comparison of filter based to photoacoustic absorption measurements. As stated in Sect. 2.1, in this study measurements were taken with a $10 \mu \mathrm{m}$ cut-off diameter. Fine mode particle mass (diameter $<2.5 \mu \mathrm{m}$ ) represented, respectively, $80 \%$ and $60 \%$ of $\mathrm{PM}_{10}$ at the pasture site (Artaxo et al., 2002) and at the forest site (Rizzo et al., 2010) during the dry season. Measurements of fine mode number size distribution during the SMOCC and LBA/ZF2-C14 experiments indicate that most particles had diameters between 10 and $400 \mathrm{~nm}$, with mean geometric diameters around $100 \mathrm{~nm}$ (Rissler et al., 2006; Rizzo et al., 2010). With the available information, it is hard to say whether there will be an underestimation or overestimation of absorption coefficients due to aerosol size effects. Even though this effect is difficult to quantify, this is important to mention. To our knowledge a comprehensive investigation concerning the sensitivity of filter based measurements to ambient aerosol size is still missing.

\subsection{Potential errors associated with the calculation of absorption coefficients}

Observations of $\omega_{0}$ and $\stackrel{\circ}{a}_{\text {scat }}$ simultaneously with attenuation measurements were not available for the three experiments analyzed here. Therefore, average values had to be used to derive the spectral dependence of the multiple scattering correction factors, $(C(\lambda)): \omega_{0}=0.92 \pm 0.02(545 \mathrm{~nm})$ and $\stackrel{\circ}{\text { scat }}_{\text {sat }}=2.0 \pm 0.4$ (Chand et al., 2006). Errors associated with the use of averages instead of specific values were evaluated through sensitivity tests.

A range of values of $\omega_{0}(0.88$ to 0.96$)$ and $\stackrel{\circ}{\text { scat }}_{\text {(1.2 }}$ to 2.8$)$ was used to calculate $C\left(\lambda, \stackrel{\circ}{a b s}_{\text {abs }}\right)$ through Eqs. (9) and (10). The correction factor $C$ was then parameterized as a function of $\stackrel{\circ}{a}_{\text {abs }}$ and $\lambda$, deriving new parameters $A$ and $B$ (similar to Eq. 12), in accordance with the method used by Schmid et al. (2006). Afterwards, the iteration procedure described in Sect. 2.3 was used to calculate $\sigma_{\text {abs }}$ and $\stackrel{\circ}{a b s}_{\text {abs }}$, evaluating deviations for different combinations of $\omega_{0}$ and $\stackrel{\circ}{\text { scat }}_{\text {. }}$.

Figure 2 shows the variability of $\sigma_{\text {abs }}$ and $\stackrel{\circ}{a b s}_{\text {abs }}$ as a function of $\omega_{0}$ and $\stackrel{\circ}{\text { scat }}_{\text {for }}$ for two measured attenuation spectra, taken as examples. Both spectra were measured in the transition period, having attenuation coefficients $\left(\sigma_{\mathrm{ATN}}\right)$ at $450 \mathrm{~nm}$ of 102 and $179 \mathrm{Mm}^{-1}$, respectively, and attenuation Ångstrom exponents $\left(\stackrel{\circ}{\mathrm{ATN}}_{\mathrm{ATN}}\right)$ of 1.72 and 1.04 , correspondingly. As $\stackrel{\circ}{\text { scat }}_{\text {. }}$ increases, the calculated $\sigma_{\text {abs }}$ and $\stackrel{\circ}{a b s}_{\text {abs }}$ decrease. The dependence of $\sigma_{\text {abs }}$ and $\stackrel{\circ}{a}_{\text {abs }}$ on $\omega_{0}$ can be approximately described by a second order polynomial, based on $\stackrel{\circ}{\text { scat }}_{\text {: }}$ as $\stackrel{\circ}{\text { scat }}_{\text {san- }}$ creases, the quadratic term of this dependence decreases. It was observed that this quadratic term can reach negative values for spectra with $\stackrel{\circ}{a}_{\text {ATN }}$ lower than approximately 1.2 , in a way that $\sigma_{\text {abs }}$ and $\stackrel{\circ}{a}_{\text {abs }}$ decrease with $\omega_{0}$ (Fig. $2 \mathrm{c}$ and d). However, in most of the cases, $\sigma_{\mathrm{abs}}$ and $\stackrel{\circ}{a b s}_{\text {abs }}$ increase with $\omega_{0}$.

The sensitivity tests indicate that the main source of error to $\sigma_{\text {abs }}$ and $\stackrel{\leftrightarrow}{a}_{\text {abs }}$ is the choice of the scattering Ångström exponent $(\stackrel{\circ}{\text { scat }})$. In the worst case, assuming the average value $\stackrel{\circ}{\text { scat }}=2.0$ may cause a maximum deviation of $\pm 10 \%$ on $\sigma_{\text {abs }}$ and $\pm 40 \%$ on $\stackrel{\circ}{a b s}_{\text {abs }}$, depending on the different possible combinations of $\stackrel{a}{s c a t}_{\text {sca }}$ and $\omega_{0}$ values. In the best case, the corresponding deviations would be $\pm 1 \%$ on $\sigma_{\text {abs }}$ and

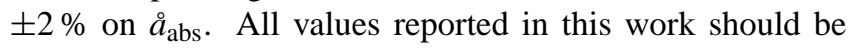
considered subject to these uncertainty ranges. However, neither worst nor best case uncertainties might be applicable for 

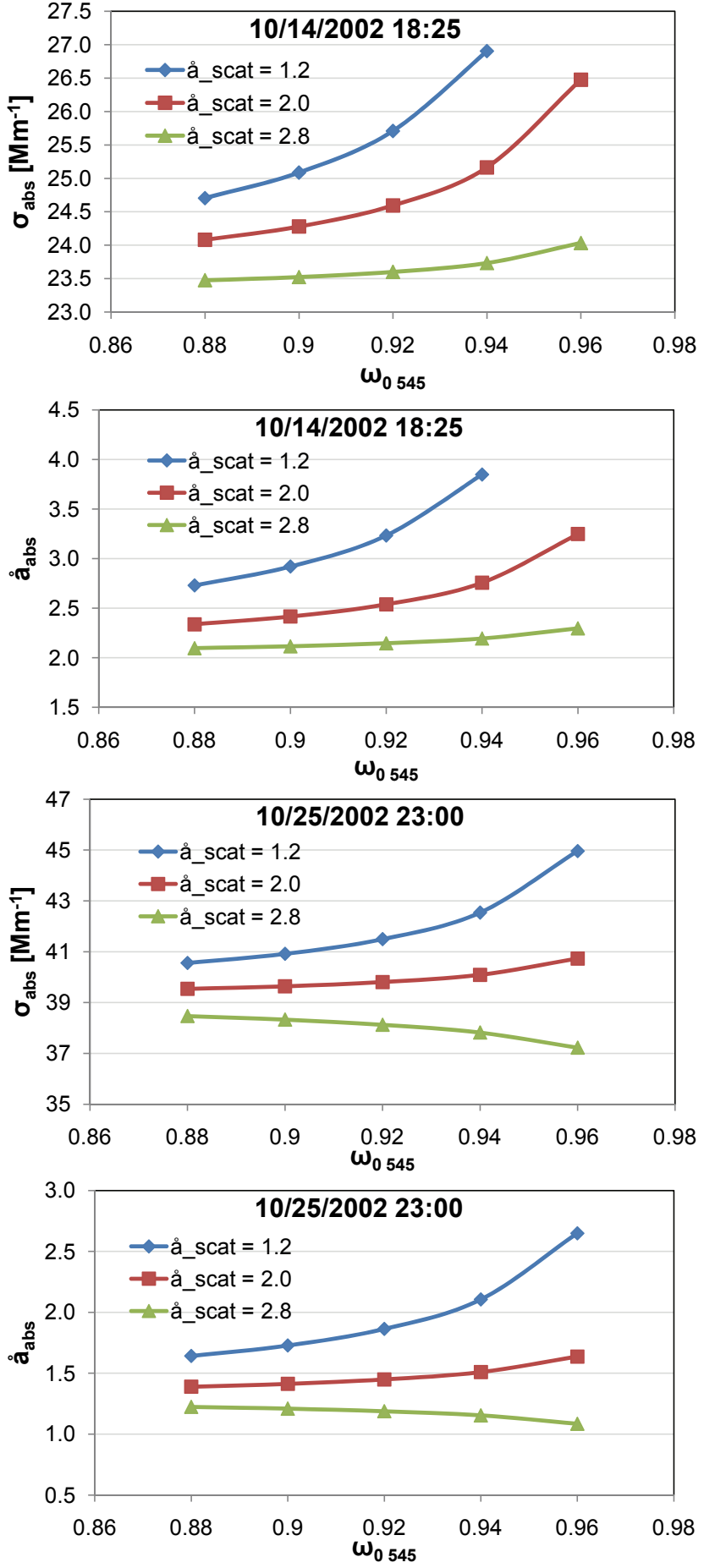

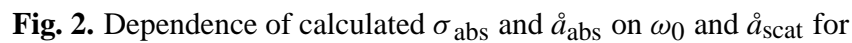
two attenuation spectra measured during the LBA/SMOCC experiment: (a), (b) 14 October 2002 18:25; (c), (d) 25 October 2002 23:00. The measured spectra had attenuation coefficients $\left(\sigma_{\text {ATN }}\right)$ at $450 \mathrm{~nm}$ of 102 and $179 \mathrm{Mm}^{-1}$, respectively, and attenuation Ångstrom exponents $(\stackrel{\circ}{\mathrm{ATN}})$ of 1.72 and 1.04 , correspondingly. every point of the dataset analyzed here. In our view, the typical uncertainties are $\pm 5 \%$ on $\sigma_{\text {abs }}$ and $\pm 20 \%$ on $\stackrel{\circ}{a b s}_{\text {. }}$.

\subsection{Data treatment}

For a systematic analysis of the aerosol absorption spectral dependence in Amazonia, the linear fit (Eq. 1), the quadratic fit (Eq. 2) and the slope between neighboring points (Eq. 3) were computed for all corrected absorption spectra from the 7-wavelength Aethalometer (Pasture Dry 1999 and Pasture Dry to Wet 2002). As will be discussed below, in most of the cases the absolute value of the curvature term $(c)$ was close to zero, so that the quadratic fit was roughly equivalent to the linear fit. For the spectra measured at two wavelengths (Forest Dry 2004), it was only possible to calculate the slope between 370 and $880 \mathrm{~nm}$ (Eq. 3).

Two criteria were used to filter the Aethalometer data sets to assure the quality of the measured spectra:

1. The adjusted $R^{2}$ of the quadratic fit should be greater than 0.85 . Adjusted $R^{2}$ means the coefficient of determination $\left(R^{2}\right)$ adjusted by the degree of freedom of the fitting. The reason for this criterion is that if a quadratic curve cannot fit satisfactorily a spectrum, it means that this particular measurement was too noisy and should not be considered as a valid observation. More than $95 \%$ of the spectra satisfied this criterion.

2. The measured attenuation should be above the detection limit of the instrument, considering its sampling time and flow. According to the Aethalometer manual, the detection limit of the instrument corresponds to a mass increase of $5 \mathrm{ng}$ on the filter. This limit can be translated into $\mathrm{Mm}^{-1}$ units using the following expression:

$\min \left(\sigma_{\mathrm{abs}}\right)=\frac{m \cdot \alpha_{\mathrm{ATN}}(\lambda)}{\Delta t \cdot Q} \quad\left[\mathrm{Mm}^{-1}\right]$,

where $m=5 \mathrm{ng}, \alpha_{\mathrm{ATN}}(\lambda)$ is the specific absorption crosssection in $\mathrm{m}^{2} \mathrm{~g}^{-1}$ (Eq. 6), $\Delta t$ is the sampling time in minutes, and $Q$ is the sampling flow in $\mathrm{d} \mathrm{m}^{3} \mathrm{~min}^{-1}$.

Obviously, only the filter criterion II could be applied to the absorption spectra measured at two wavelengths only.

Equation (13) was used to calculate the Aethalometer detection limit for the different field studies considered here, as shown in Table 1. This table also shows the total number of observed attenuation spectra, as well as the percentage of spectra satisfying the criteria described above.

\section{Results and discussion}

Average absorption spectra calculated for the three field experiments are shown in Fig. 3. The SMOCC campaign was divided into three periods, dry, transition and wet, as described before (Sect. 2.1). The averages included all spectra that fulfilled the filtering criteria mentioned in Sect. 2.5. 
Table 1. For all the field experiments considered in this analysis, this table shows: measurement period; Aethalometer sampling time; calculated detection limit at $450 \mathrm{~nm}$; total number of measured attenuation spectra; percentage of spectra satisfying the filtering criteria described in the text. (* detection limit at $370 \mathrm{~nm}$ ).

\begin{tabular}{|c|c|c|c|c|c|}
\hline Experiment & $\begin{array}{l}\text { Measurement } \\
\text { period }\end{array}$ & $\begin{array}{l}\text { Sampling time } \\
\text { (min) }\end{array}$ & $\begin{array}{l}\text { Detection limit at } \\
450 \mathrm{~nm}\left(\mathrm{Mm}^{-1}\right)\end{array}$ & $\begin{array}{l}\text { Number of measured } \\
\text { spectra }\end{array}$ & $\begin{array}{l}\text { Percent of spectra satisfying } \\
\text { the filtering criteria }\end{array}$ \\
\hline Forest Dry 2004 LBA/ZF2-C14 & 13 Aug-1 Oct 2004 & 5 & $10.0^{*}$ & 9618 & $90 \%$ \\
\hline Pasture Dry to Wet 2002 LBA/SMOCC & 5 Sep-14 Nov 2002 & 15 & 2.0 & 5840 & $90 \%$ \\
\hline Pasture Dry 1999 LBA/EUSTACH & 17 Sep-26 Oct 1999 & 10 & 2.0 & 4684 & $91 \%$ \\
\hline
\end{tabular}

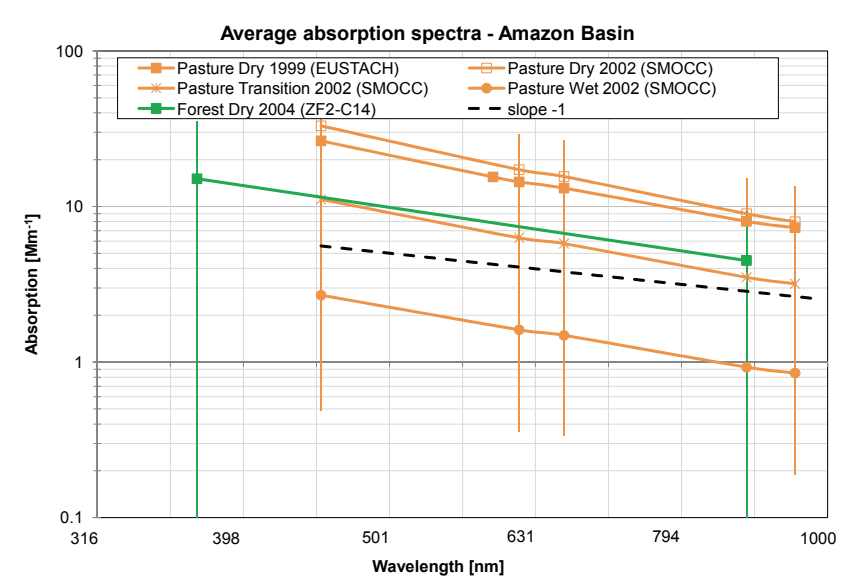

Fig. 3. Average aerosol absorption spectra for: Pasture Dry 1999 (EUSTACH) - comprising 4265 spectra; Pasture Dry to Wet 2002 (SMOCC) - comprising 5296 spectra; Forest Dry 2004 (ZF2-C14) - comprising 7927 spectra. Error bars represent statistical standard deviations. Also shown is a spectrum with a slope of -1 , characteristic of soot aerosol (black dashed line).

As expected, greater absorption values were observed during the dry season, as a consequence of biomass burning emissions. Note the good agreement between Pasture Dry 1999 (EUSTACH) and Pasture Dry 2002 (SMOCC) curves, measured at the same pasture site within a period of three years. From the dry to the wet season, aerosol absorption at $450 \mathrm{~nm}$ decreased approximately by a factor of 10 at the pasture site. Absorption coefficients at the forest site during the dry season are intermediate in magnitude between the Pasture Dry and Pasture Wet curves. While there were no local fires at the forest site, the location was influenced by regional biomass burning emissions carried along by air masses. An absorption spectrum with slope of -1 , typical of soot aerosols, is represented in Fig. 3 by a dashed black line.

To assess the variability of the spectral dependence over the averages represented in Fig. 3, Ångström exponents were calculated for each absorption spectrum measured during the three field campaigns, considering the filtering criteria stated in Sect. 2.3. Here will be discussed the variability of absorption Ångström exponents calculated through a linear fit over the whole spectrum (Eq. 1) ( $\dot{a}_{\mathrm{abs}}^{\text {lin }}$ ), and as the negative slope between two neighboring wavelength values (Eq. 3$)\left(\stackrel{\leftrightarrow}{a}_{\mathrm{abs}}^{450 / 615}\right.$ and $a_{\text {abs }}^{370 / 880}$ ). Fig. 4 shows histograms of $a_{\text {abs }}^{\text {lin }}$ for the three field campaigns.

At the pasture site, 60 to $70 \%$ percent of $\stackrel{a}{a b s}$ lin $_{\text {(Fig. } 4 \mathrm{a}}$ and $b$ ) fell between 1.5 and 2.5 during the dry season. This is in accordance with Kirchstetter et al. (2004), who reported absorption Ångström exponents of approximately 2.0 for biomass burning aerosols, as a result of enhanced light absorption at wavelengths shorter than $600 \mathrm{~nm}$. The authors suggest that low-temperature and incomplete combustion processes, such as biomass burning, can produce absorbing aerosols with a stronger spectral dependence as compared to high-temperature combustion processes that generate soot.

Particularly during the SMOCC experiment, it was possible to observe a consistent decrease of the average absorption Ångström exponent as the weather regime moved from dry to wet season (Fig. 4b). Figure 5 shows that, from dry to wet season, the percentage of fine mode particles in $\mathrm{PM}_{10}$ mass decreased from $80 \%$ to about $50 \%$, a sign of the shift from biomass burning aerosols, predominant in the fine mode, to biogenic and dust aerosols, predominant in the coarse mode. Also, Fig. 6 shows that in the SMOCC experiment low absorption coefficients were associated with Ångström exponents below 1.0, with a typical uncertainty of $\pm 20 \%$ (refer to Sect. 2.4). That also holds for the other two experiments, indicating that the Amazonian natural aerosol population has a weaker absorption spectral dependence than biomass burning aerosols.

The reason for reduced Ångström exponents during the wet season can be attributed either to the increase of particle sizes (Fig. 5) or to a change in the physicochemical properties of the aerosol population. The variation of absorption spectral dependency as a function of aerosol bulk properties is still not well understood, especially for biogenic aerosols. Nevertheless, the effect of particle size changes on absorption Ångström exponents is relatively well known. For example, Moosmüller et al. (2011a) modeled the absorption spectra of homogeneous spherical brown carbon particles and found a decrease of Ångström exponents for larger particle diameters (from 0.1 to $10 \mu \mathrm{m}$ ). A similar result has been found by Gyawali et al. (2009) for uncoated black carbon spheres. In addition to the effect of aerosol size, another possible explanation would be the rain scavenging of soluble 

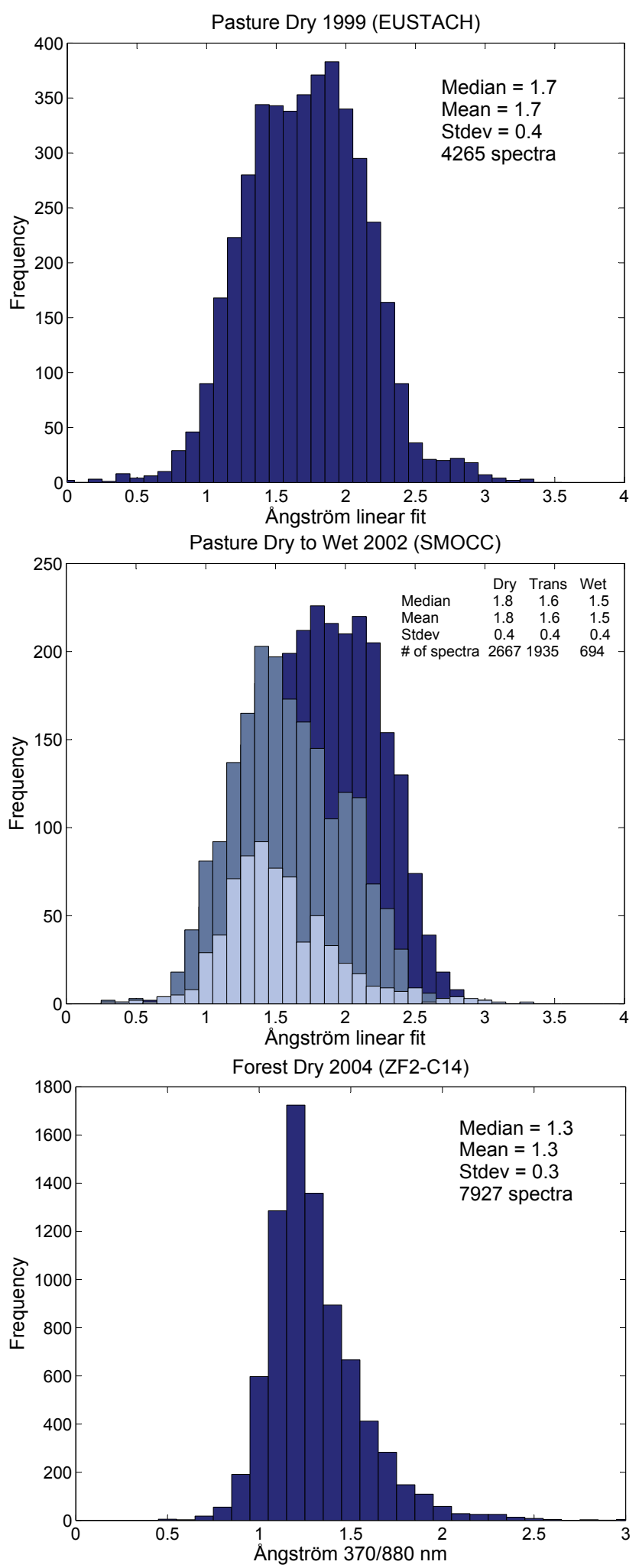

Fig. 4. Histograms of absorption Ångström exponents for the field experiments: (a) Pasture Dry 1999 (LBA/EUSTACH); (b) Pasture Dry to Wet 2002 (LBA/SMOCC); (c) Forest Dry 2004 (LBA/ZF2C14). The typical uncertainty in $\stackrel{\circ}{a b s}_{\text {abs }} \pm 20 \%$ (refer to Sect. 2.4).
Pasture Dry to Wet 2002 - LBA/SMOCC Ratio PM2.5/PM10 (\%)

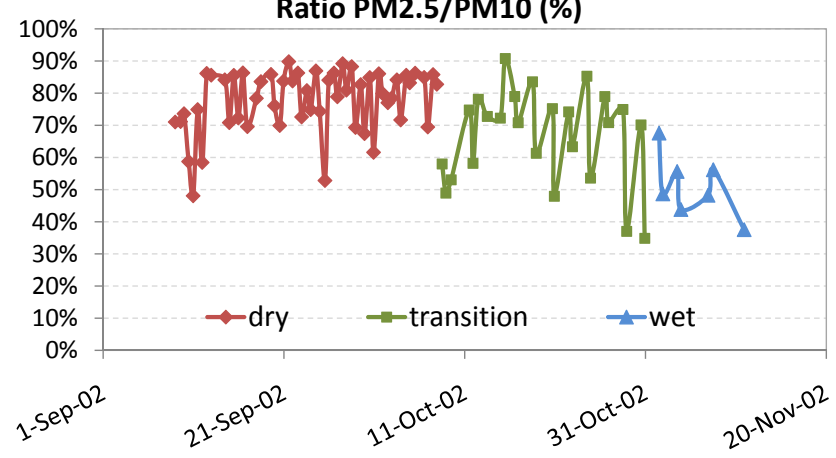

Fig. 5. Percent contribution of $\mathrm{PM}_{2.5}$ to $\mathrm{PM}_{10}$ aerosol mass concentration during the LBA/SMOCC experiment, based on gravimetric analysis of polycarbonate filters. The percentage of $\mathrm{PM}_{2.5}$ decreases from dry to wet season, in accordance with the shift from biomass burning to biogenic aerosols.

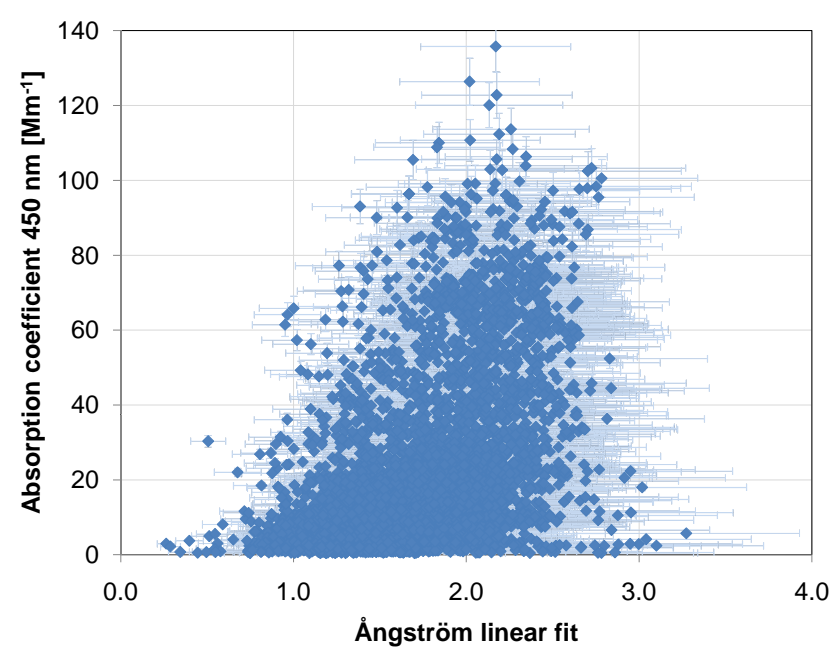

Fig. 6. Aerosol absorption coefficients at $450 \mathrm{~nm}$ versus Ångström exponents calculated by a linear fit over the observed spectral range $(450-950 \mathrm{~nm}$ ) for the SMOCC experiment data (Pasture Dry to Wet 2002). Error bars represent typical uncertainties: $\pm 5 \%$ in $\sigma_{\text {abs }}$ and $\pm 20 \%$ in $\stackrel{\circ}{a b s}_{\text {. }}$.

organic aerosols during the wet season, resulting in an enrichment of insoluble soot carbon particles in the remaining aerosol. This effect could also shift the Ångström exponents to lower values from dry to wet season.

The lowest Ångström exponents were observed at the forest site in the dry season (LBA/ZF2-C14 experiment), with a mean value of $\stackrel{a}{a}_{\mathrm{abs}}^{370 / 880}=1.3 \pm 0.3$ (Fig. 4c). As this forest site is in a remote preserve, even during the dry season biogenic particles comprise the majority of the particulate matter $(75 \%)$, while other light absorbing particles (soil dust and soot-like) account for $13 \%$ of the total aerosol mass (Rizzo et al., 2010). The fact that $90 \%$ of the observed Ångström 
Table 2. Average absorption coefficient measured for each field experiment, as well as average Ångström exponents calculated through linear fit $\left(\dot{a}_{\text {abs }}^{\text {lin }}\right)$, through the slope between 450 and $615 \mathrm{~nm}\left(\stackrel{\leftrightarrow}{a}_{\text {abs }}^{450 / 615}\right)$ and between 370 and $880 \mathrm{~nm}\left(\stackrel{(}{a}_{\text {abs }}^{370 / 880}\right)$. Also shown the percentage of spectra in which the linear fit was a good approximation (adjusted $\left.R^{2}>0.90\right)$. ( ${ }^{*}$ absorption at $370 \mathrm{~nm}$; ${ }^{* *}$ equivalent to $\stackrel{a}{\text { abs }}^{370 / 880}$ ).

\begin{tabular}{|c|c|c|c|c|}
\hline Experiment & $\begin{array}{l}\sigma_{\mathrm{abs}} \\
(450) \mathrm{Mm}^{-1}\end{array}$ & $\begin{array}{l}\text { Ångström Linear Fit } \\
(\stackrel{\circ}{\operatorname{lin}})\end{array}$ & $\begin{array}{l}\text { Ångström } 450 / 615 \mathrm{~nm} \\
\left(\stackrel{\circ}{a}_{450 / 615}\right)\end{array}$ & $\begin{array}{l}\text { Percent of spectra } \\
\text { with good linear fit }\end{array}$ \\
\hline Forest Dry 2004 (ZF2-C14) & $11 \pm 8^{*}$ & $1.3 \pm 1.3^{* *}$ & - & - \\
\hline Pasture 2002 (SMOCC) & $21 \pm 22$ & $1.7 \pm 0.4$ & $1.8 \pm 0.6$ & $99 \%$ \\
\hline Pasture Dry 2002 (SMOCC) & $33 \pm 5$ & $1.8 \pm 0.4$ & $1.9 \pm 0.5$ & $100 \%$ \\
\hline Pasture Transition 2002 (SMOCC) & $11 \pm$ & $1.6 \pm 0.4$ & $1.7 \pm 0.5$ & $99 \%$ \\
\hline Pasture Wet 2002 (SMOCC) & $2.7 \pm 0.2$ & $1.5 \pm 0.4$ & $1.6 \pm 0.7$ & $95 \%$ \\
\hline Pasture Dry 1999 (EUSTACH) & $26 \pm 1$ & $1.7 \pm 0.4$ & $1.9 \pm 0.6$ & $94 \%$ \\
\hline
\end{tabular}

Table 3. First-order estimate of the $24 \mathrm{~h}$ radiative forcing between 450 and $880 \mathrm{~nm}$ at the surface, top of atmosphere (TOA), and in the atmosphere, considering AOT $=1.0$ and different spectral dependencies for the absorption coefficient.

\begin{tabular}{lllll}
\hline $\begin{array}{l}\text { Absorption Ångström } \\
\text { exponent }\end{array}$ & $\begin{array}{l}\text { Extinction Ångström } \\
\text { exponent }\end{array}$ & $\begin{array}{l}\text { Forcing at surface } \\
{\left[\mathrm{W} \mathrm{m}^{-2}\right]}\end{array}$ & $\begin{array}{l}\text { Forcing at TOA } \\
{\left[\mathrm{W} \mathrm{m}^{-2}\right]}\end{array}$ & $\begin{array}{l}\text { Forcing in atmosphere } \\
{\left[\mathrm{W} \mathrm{m}^{-2}\right]}\end{array}$ \\
\hline 1.0 & 1.92 & -32.07 & -8.03 & 24.04 \\
1.4 & 1.95 & -32.03 & -8.05 & 23.99 \\
1.8 & 1.98 & -32.00 & -8.07 & 23.93 \\
2.2 & 2.02 & -31.95 & -8.10 & 23.86 \\
\hline
\end{tabular}

exponents are below 1.5 ( \pm with a typical uncertainty of $20 \%$ ) reinforces the point that Amazonian biogenic particles may have a weak spectral dependence for absorption. This finding contradicts our expectations of biogenic particles behaving as "brown carbon", i.e., particles that show absorption coefficients sharply increasing at wavelengths below $600 \mathrm{~nm}$. Nevertheless, additional measurements should be performed at forest sites in Amazonia to provide a complete picture of biogenic aerosol absorption spectral characteristics regarding different seasons and geographic locations.

Table 2 summarizes the average magnitude of aerosol absorption observed at each site and season considered in this study, which agrees with previously reported data (Artaxo et al., 2002; Schmid et al., 2006; Chand et al., 2006). It also shows the corresponding average Ångström exponents $a_{\text {abs }}^{\text {lin }}$, $\stackrel{\circ}{a b s}^{450 / 615}$ and $\stackrel{\circ}{a b s}^{370 / 880}$. Considering the standard deviations,

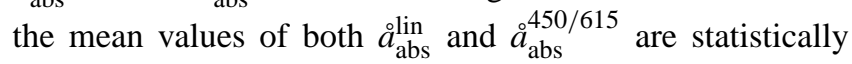
comparable for all measurements taken at the pasture site. The percentage of spectra in which the linear fit was a good approximation (adjusted $R^{2}$ greater than 0.90), was above $94 \%$, indicating that in most of the cases the Angström exponent was approximately constant throughout the observed spectral region.

Figure 7 shows the cumulative histogram of Ångström exponents for the field studies in which the 7-wavelength Aethalometer was available. It indicates the variability of Ångström exponents as a function of wavelength. The spectral dependence between 450 and $615 \mathrm{~nm}$ can be up to $10 \%$ steeper than the Ångström exponent derived from the complete measured spectra $(450-950 \mathrm{~nm})$. Also, this $10 \%$ difference between $\stackrel{\circ}{a}_{\mathrm{abs}}^{450 / 615}$ and $\stackrel{\text { olin }}{\mathrm{abs}}$ does not justify the application of quadratic fits to the aerosol absorption spectra. The linear fit was a good approximation in more than $94 \%$ of the observed spectra (Table 2).

At the pasture site, Ångström exponents observed during the day were about $20 \%$ lower than at nighttime (Fig. 8). The diurnal cycle of absorption coefficients and aerosol number concentration (not shown) follow a similar pattern, most likely a consequence of the dynamics of the boundary layer. Chand et al. (2006) reported higher albedo values for the SMOCC experiment during daytime, and argued that diurnal aerosols are more aged than the nocturnal ones. Aged smoke particles undergo a size increase due to coagulation and condensation of inorganic and organic species, with impacts on aerosol optical properties (Reid et al., 1998). Accordingly, Rissler et al. (2006) observed higher aerosol modal diameters during daytime compared to nighttime for the SMOCC experiment. The decreased absorption Ångström exponents observed at daytime might be either an outcome of increased particle sizes (Moosmüller et al., 2011a), or a consequence of changes in particle chemical composition due to combustion conditions or biomass fuel type, or even a consequence of the condensation of absorbing species with a weaker spectral dependence to the surface of aerosols.

We made a first order estimate of the influence of the observed absorption Ångström exponents on the aerosol 

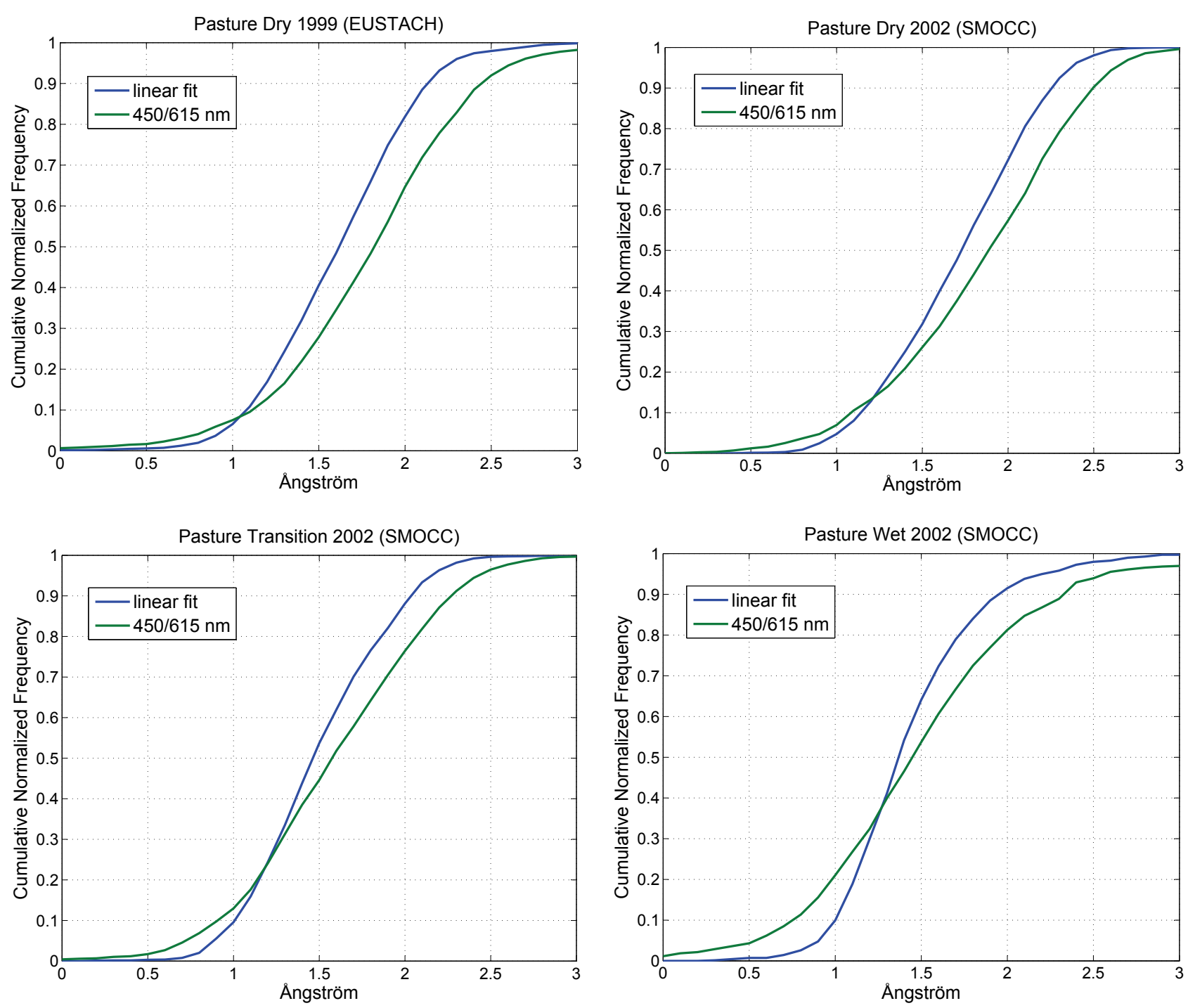

Fig. 7. Cumulative histogram of absorption Ångström exponents for: (a) Pasture Dry 1999 (LBA/EUSTACH); (b) Pasture Dry 2002; (c) Pasture Transition 2002 and (d) Pasture Wet 2002 (LBA/SMOCC). Ångström exponents were calculated based on the slope between neighboring wavelengths $\left(\stackrel{\leftrightarrow}{a}_{\text {abs }}^{450 / 615}\right)$ and based on linear fits over the whole measured spectrum $\left(\stackrel{\circ}{a}\right.$ abs $\left._{\text {lin }}\right)$. The typical uncertainty in $\stackrel{\leftrightarrow}{a}_{\text {abs }}$ is $\pm 20 \%$ (refer to Sect. 2.4).

radiative forcing. The $24-\mathrm{h}$ aerosol radiative forcing was calculated assuming an aerosol optical thickness (AOT) of 1.0 at $500 \mathrm{~nm}$, typically observed in Amazonia during the dry season (Procopio et al., 2004), over a vegetated surface. The radiative fluxes were calculated between 450 and $880 \mathrm{~nm}$ by means of SBDART (Santa Barbara DISORT Atmospheric Radiative Transfer), using zero AOT as reference to calculate the aerosol forcings. The latitude of $5^{\circ} \mathrm{S}$ and the Julian day 258 were assumed in the calculations, representing the average latitude of the Amazon Region and the middle of the dry season, respectively. Aerosol optical properties at $500 \mathrm{~nm}$ were derived from a dynamic spectral aerosol model developed by Procopio et al. (2003) for smoke aerosols in Amazonia. The spectral dependency of aerosol optical prop- erties was extrapolated using four extinction Ångström exponents $\left(\stackrel{\circ}{e x t}_{\text {ext }}\right)$, calculated using the following equation taken from Moosmüller et al. (2011b):

$\stackrel{\circ}{\mathrm{axt}}_{\mathrm{ext}}=\left[1-\omega_{0}(\lambda)\right] \stackrel{\circ}{\mathrm{abs}}(\lambda)+\omega_{0}(\lambda) \stackrel{\circ}{\mathrm{a}}_{\mathrm{scat}}(\lambda)$,

The single scattering albedo and the scattering Ångström exponent were assumed to be 0.92 and 2.0, respectively (Chand et al., 2006), and independent of wavelength in the spectral range under consideration. This is a reasonable assumption, as we estimate a weak spectral dependency for $\omega_{0}$, ranging from 0.92 at $450 \mathrm{~nm}$ to 0.91 at $880 \mathrm{~nm}$. Four values of $\stackrel{\leftrightarrow}{a}_{\text {abs }}$ were considered for the 24-h aerosol forcing calculations: 1.0 (usual absorption spectral dependency assumed for soot carbon); 1.4 (corresponding to the average of $a_{a \mathrm{abs}}^{\mathrm{lin}}$ for 


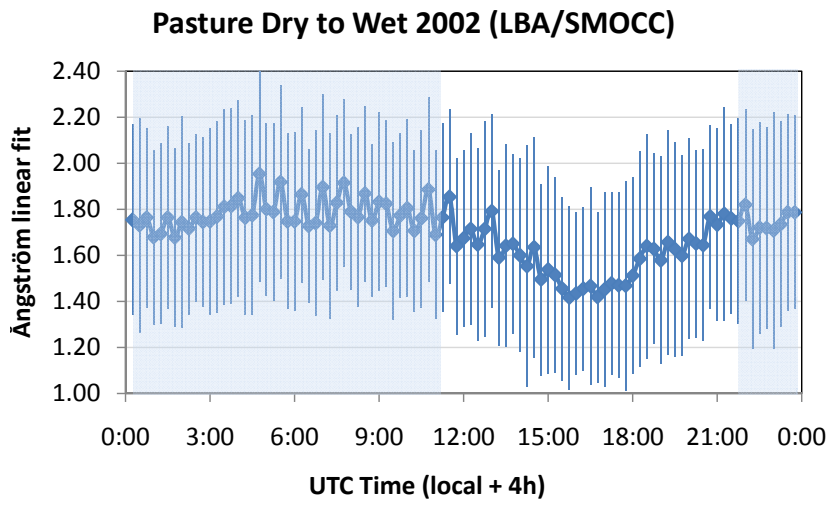

Fig. 8. Average diurnal cycle of the $\stackrel{a}{a}$ abs $_{\text {ab }}$ Ånström exponents calculated for Pasture Dry to Wet 2002 (SMOCC). Bars represent statistical standard deviations. Shaded areas represent nighttime periods.

the Pasture Dry 2002 experiment minus one standard deviation - refer to Table 2); 1.8 (average of $\stackrel{a}{\text { abs }}$ fin $_{\text {for }}$ fo Pasture Dry 2002 experiment); and 2.2 (average of $a_{\text {abs }}^{\text {lin }}$ for the Pasture Dry 2002 experiment plus one standard deviation). The value of $\stackrel{\circ}{a b s}_{\text {abs }}$ was also assumed to be wavelength independent, in accordance with our results (Table 2). Aerosols were assumed to be distributed homogenously in an atmospheric layer of $1.6 \mathrm{~km}$ of altitude.

Table 3 shows a first order assessment of the variability of the 24-h aerosol radiative forcing as a function of absorption Ångström exponents. The mean forcing found with this parameterization for $\mathrm{AOT}=1(500 \mathrm{~nm})$ was $-32 \mathrm{~W} \mathrm{~m}^{-2}$ at the surface and $-8 \mathrm{~W} \mathrm{~m}^{-2}$ at the top of atmosphere (TOA), with $24 \mathrm{~W} \mathrm{~m}^{-2}$ being absorbed in the atmosphere. This result is comparable to other studies conducted in the Amazonian region, e.g., Procopio et al. (2004). Changing $\stackrel{\leftrightarrow}{a}_{\text {abs }}$ from 1.0 to 2.2 causes a reduction of less than $1 \%$ in the absolute values of instantaneous aerosol forcing at the surface and in the atmosphere. At TOA, the instantaneous forcing calculated assuming $\stackrel{\circ}{a b s}_{a}=2.2$ can be up to $4.5 \%$ greater in absolute values compared to the forcing calculated assuming the absorption spectral dependency of soot aerosol $\left(\stackrel{a}{a b s}_{a}=1.0\right)$. For the 24-h aerosol forcing at TOA, the corresponding increase is about $0.9 \%$. Overall, the results indicate a small effect of absorption Ångström exponents on 24-h aerosol forcings, at least in the spectral region of $450-880 \mathrm{~nm}$. Further studies should be taken to assess the corresponding impact in the UV spectral range.

\section{Summary and conclusions}

The inference of aerosol absorption coefficients from attenuation coefficients requires a previous knowledge of the spectral dependency of the single scattering albedo, among other parameters. In the absence of the necessary supporting measurements, average values were used to obtain corrected ab- sorption coefficients from Aethalometer observations. Errors associated with the use of averages instead of specific values of single scattering albedo and scattering Ångström exponents were evaluated through sensitivity tests. A precise value for the uncertainty of absorption coefficients or Ångström exponents is not achievable, but it is possible to predict a range of uncertainties. We estimate the typical uncertainties as $\pm 5 \%$ on $\sigma_{\mathrm{abs}}$ and $\pm 20 \%$ on $\mathrm{a}_{\mathrm{abs}}$. All values reported in this work should be considered subject to these uncertainties.

The magnitude and wavelength dependence of aerosol absorption in Amazonia was studied for different sites and seasons. As expected, greater absorption values were observed at the pasture site during the dry season, as a consequence of biomass burning emissions, with average values around $30 \mathrm{Mm}^{-1}$ at $450 \mathrm{~nm}$. At the onset of the wet season, aerosol absorption coefficients decreased by one order of magnitude (to $2.7 \mathrm{Mm}^{-1}$ at $450 \mathrm{~nm}$ on average). Absorption coefficients at the forest site during the dry season were intermediate in magnitude, falling between the observations taken during the dry and wet seasons at the pasture site.

Absorption Ångström exponents did not vary significantly with wavelength, so that, in most cases, a power law fit could be applied over the whole measured spectral range (450-

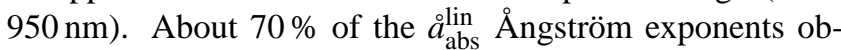
served at the pasture site during the dry season fell between 1.5 and 2.5, suggesting the presence of light-absorbing organic carbon (brown carbon) released from biomass burning emissions. Average diurnal cycles of Ångström exponents for the pasture site showed a clear pattern, with values $20 \%$ lower at daytime, when the aerosol population is dominated by larger and more aged particles (Chand et al., 2006; Rissler et al., 2006). The decreased Ångström exponents during the day might be either an outcome of increased particle sizes (Moosmüller et al., 2011a),or a consequence of changes in particle chemical composition due to combustion conditions or biomass fuel type, or also a consequence of the condensation of absorbing species with a weaker spectral dependence to the surface of aerosols.

At the pasture site, throughout the transition from dry to wet season, average absorption Ångström exponents decreased, in agreement with the shift from biomass burning aerosols, predominant in the fine mode, to biogenic and dust aerosols, predominant in the coarse mode. Low Ångström exponents (below 1.5) were also observed in $90 \%$ of the absorption spectra measured at the forest site during the dry season. Results indicate that low absorption coefficients (below ca. $15 \mathrm{Mm}^{-1}$ at $450 \mathrm{~nm}$ ), typically observed under unpolluted conditions in Amazonia, are associated with Ångström exponents below 1.0. This finding suggests that biogenic aerosols from Amazonia may have a weak spectral dependence for absorption when compared to biomass burning aerosols, contradicting our expectations of biogenic particles behaving as brown carbon. Nevertheless, additional measurements should be taken in the future, 
to provide a complete picture of biogenic aerosol absorption spectral characteristics in different seasons and geographic locations. In a first order assessment, results indicate a small $(<1 \%)$ effect of variations in absorption Ångström exponents on 24-h aerosol forcings, at least in the spectral range of $450-880 \mathrm{~nm}$. Further studies should be taken to assess the corresponding impact in the UV spectral range. Our results show that caution must be taken when extrapolating aerosol absorption measured at one single wavelength over the entire solar spectrum. The assumption that soot spectral properties represent all ambient light absorbing particles may cause an underestimation of absorption in the UV spectral range. Especially in remote areas, where non-soot light absorbing aerosols predominate, it is advisable to measure aerosol absorption at several wavelengths to accurately assess the impact of these particles on climate and photochemical atmospheric processes. If measurements are taken using a filterbased attenuation method, it is advisable to have simultaneous observations of aerosol scattering at several wavelengths and a reference absorption measurement for proper calibration.

Acknowledgements. We thank all members of the LBA/EUSTACH, LBA/SMOCC and LBA/ZF2-C14 Tower Experiments. We also thank Alcides C. Ribeiro, Ana L. Loureiro and Társis Germano (IFUSP) for the assistance and logistical support during sampling. This study was financed by FAPESP (Fundação de Amparo à Pesquisa do Estado de São Paulo) and Millennium Institute program from MCT/CNPq. Additional funding has been provided by the German Max Planck Society and by the European Commission.

Edited by: T. Kirchstetter

\section{References}

Albuquerque, L. M. M., Longo, K. M., Freitas, S. R., Tarasova, T., Plana Fattori, A., Nobre, C., and Gatti, L. V.: Sensitivity studies on the photolysis rates calculation in Amazonian atmospheric chemistry - Part I: The impact of the direct radiative effect of biomass burning aerosol particles, Atmos. Chem. Phys. Discuss., 5, 9325-9353, doi:10.5194/acpd-5-9325-2005, 2005.

Alexander, D. T. L., Crozier, P. A., and Anderson, J. R.: Brown carbon spheres in East Asian outflow and their optical properties, Science, 321, 833-836, 2008.

Andreae, M. O. and Crutzen, P. J.: Atmospheric aerosols: Biogeochemical sources and role in atmospheric chemistry, Science, 276, 1052-1056, 1997.

Andreae, M. O., Artaxo, P., Fischer, H., Freitas, S. R., Grégoire, J.-M., Hansel, A., Hoor, P., Kormann, R., Krejci, R., Lange, L., Lelieveld, J., Lindinger, W., Longo, K., Peters, W., de Reus, M., Scheeren, B., Silva Dias, M. A. F., Ström, J., van Velthoven, P. F. J., and Williams, J.: Transport of biomass burning smoke to the upper troposphere by deep convection in the equatorial region, Geophys. Res. Lett., 28, 951-954, doi:10.1029/2000GL012391, 2001.

Andreae, M. O., Artaxo, P., Brandão, C., Carswell, F. E., Ciccioli, P., da Costa, A. L., Culf, A. D., Esteves, J. L., Gash, J.
H. C., Grace, J., Kabat, P., Lelieveld, J., Malhi, Y., Manzi, A. O., Meixner, F. X., Nobre, A. D., Nobre, C., Ruivo, M. d. L. P., Silva-Dias, M. A., Stefani, P., Valentini, R., von Jouanne, J., and Waterloo, M. J.: Biogeochemical cycling of carbon, water, energy, trace gases, and aerosols in Amazonia: The LBAEUSTACH experiments, J. Geophys. Res., 107(D20), 8066, doi:10.1029/2001JD000524, 2002.

Andreae, M. O., Rosenfeld, D., Artaxo, P., Costa, A. A., Frank, G. P., Longo, K. M., and Silva-Dias, M. A. F.: Smoking rain clouds over the Amazon, Science, 303, 1337-1342, 2004.

Andreae, M. O. and Gelencsér, A.: Black carbon or brown carbon? The nature of light-absorbing carbonaceous aerosols, Atmos. Chem. Phys., 6, 3131-3148, doi:10.5194/acp-6-3131-2006, 2006.

Ångström, A.: On the atmospheric transmission of sun radiation and on dust in the air, Geograf. Ann., 11, 156-166, 1929.

Arnott, W. P., Hamasha, K., Moosmüller, H., Sheridan, P. J., and Ogren, J. A.: Towards aerosol light-absorption measurements with a 7-wavelength aethalometer: Evaluation with a photoacoustic instrument and 3-wavelength nephelometer, Aerosol Sci. Technol., 39, 17-29, 2005.

Artaxo P., Martins, J. V., Yamasoe, M. A., Procópio, A. S., Pauliquevis, T. M., Andreae, M. O., Guyon, P., Gatti, L. V., and Leal, A. M. C.: Physical and chemical properties of aerosols in the wet and dry seasons in Rondônia, Amazonia, J. Geophys. Res., 107(D20), 8081, doi:10.1029/2001JD000666, 2002.

Avissar, R., Silva Dias, P. L., Silva Dias, M. A. F., and Nobre, C.: The Large-Scale Biosphere-Atmosphere Experiment in Amazonia (LBA): Insights and future research needs. J. Geophys. Res., 107(D20), 8086, doi:10.1029/2002JD002704, 2002.

Bergstrom, R. W., Pilewskie, P., Russell, P. B., Redemann, J., Bond, T. C., Quinn, P. K. and Sierau, B.: Spectral absorption properties of atmospheric aerosols, Atmos. Chem. Phys., 7, 5937-5943, doi:10.5194/acp-7-5937-2007, 2007.

Bond, T. C. and Bergstrom, R. W.: Light absorption by carbonaceous particles: An investigative review, Aerosol Sci. Tech., 40, 27-67, 2006.

Chand, D., Guyon, P., Artaxo, P., Schmid, O., Frank, G. P., Rizzo, L. V., Mayol-Bracero, O. L., Gatti, L. V. and Andreae, M. O.: Optical and physical properties of aerosols in the boundary layer and free troposphere over the Amazon Basin during the biomass burning season, Atmos. Chem. Phys., 6, 2911-2925, doi:10.5194/acp-6-2911-2006, 2006.

Collaud Coen, M., Weingartner, E., Apituley, A., Ceburnis, D., Fierz-Schmidhauser R., Flentje, H., Henzing J. S., Jennings, S. G., Moerman, M., Petzold, A., Schmid, O., and Baltensperger, U.: Minimizing light absorption measurement artifacts of the Aethalometer: evaluation of five correction algorithms, Atmos. Meas. Tech., 3, 457-474, doi:10.5194/amt-3-457-2010, 2010.

Davidson, E. A. and Artaxo, P.: Globally significant changes in biological processes of the Amazon Basin: Results of the Largescale Biosphere-Atmosphere Experiment, Global Change Biol., 10(5), 1-11, doi:10.1111/j.1529-8817.2003.00779, 2004.

Freitas, S. R., Longo, K. M., Silva Dias, M. A. F., Silva Dias, P. L., Chatfield, R., Prins, E., Artaxo, P., Grell, G. A., and Recuero, F. S.: Monitoring the transport of biomass-burning emissions in South America, Environ. Fluid Mech., 5, 135-167, doi:10.1007/s10652-005-0243-7, 2005.

Fuzzi, S., Andreae, M. O., Huebert, B. J., Kulmala, M., Bond, 
T. C., Boy, M., Doherty, S. J., Guenther, A., Kanakidou, M., Kawamura, K., Kerminen, V.-M., Lohmann, U., Russell, L. M. and Pöschl, U.: Critical assessment of the current state of scientific knowledge, terminology, and research needs concerning the role of organic aerosols in the atmosphere, climate, and global change, Atmos. Chem. Phys., 6, 2017-2038, doi:10.5194/acp-62017-2006, 2006.

Fuzzi, S., S. Decesari, M. C. Facchini, F. Cavalli, L. Emblico, M. Mircea, M. O. Andreae, I. Trebs, A. Hoffer, P. Guyon, P. Artaxo, L. V. Rizzo, L. L. Lara, T. Pauliquevis, W. Maenhaut, N. Raes, X. Chi, O. L. Mayol-Bracero, L. L. Soto-García, M. Claeys, I. Kourtchev, J. Rissler, E. Swietlicki, E. Tagliavini, G. Schkolnik, A. H. Falkovich, Y. Rudich, G. Fisch and L. V. Gatti: Overview of the inorganic and organic composition of size-segregated aerosol in Rondônia, Brazil, from the biomass burning period to the onset of the wet season, J. Geophys. Res., 112, D01201, doi:10.1029/2005JD006741, 2007.

Gyawali, M., Arnott, W. P., Lewis, K., and Moosmüller, H.: In situ aerosol optics in Reno, NV, USA during and after the summer 2008 California wildfires and the influence of absorbing and non-absorbing organic coatings on spectral light absorption, Atmos. Chem. Phys., 9, 8007-8015, doi:10.5194/acp-9-8007-2009, 2009.

Hansen, J., Sato, M., and Ruedy, R.: Radiative forcing and climate response, J. Geophys. Res., 102, 6831-6864, 1997.

Hoffer, A., Gelencsér, A., Guyon, P., Kiss, G., Schmid, O., Frank, G. P., Artaxo, P., and Andreae, M. O.: Optical properties of humic-like substances (HULIS) in biomass-burning aerosols, Atmos. Chem. Phys., 6, 3563-3570, doi:10.5194/acp-6-3563-2006, 2006a.

Hoffer, A., Gelencsér, A., Blazsó, M., Guyon, P., Artaxo, P. and Andreae, M. O.: Diel and seasonal variations in the chemical composition of biomass burning aerosol, Atmos. Chem. Phys., 6, 3505-3515, doi:10.5194/acp-6-3505-2006, 2006b.

IPCC, Climate Change 2007: The Physical Science Basis. Contribution of Working Group I to the Fourth Assessment Report of the Intergovernmental Panel on Climate Change, edited by: Solomon, S., Qin, D., Manning, M., Chen, Z., Marquis, M., Averyt, K., Tignor, M., and Miller, H. L., Cambridge University Press, Cambridge and New York, USA, 996 pp., 2007.

Jacobson, M. Z.: Isolation nitrated and aromatic aerosols and nitrated aromatic gases as sources of ultraviolet light absorption, J. Geophys. Res., 104, 3527-3542, 1999.

Kirchstetter, T. W., Novakov, T., and Hobbs, P. V.: Evidence that the spectral dependence of light absorption by aerosols is affected by organic carbon, J. Geophys. Res., 109, D21208, doi:10.1029/2004JD004999, 2004.

Lack, D. A., Cappa, C. D., Cross, E. S., Massoli, P., Ahern, A. T., Davidovits, P., and Onasch, T. B.: Absorption enhancement of coated absorbing aerosols: validation of the photo-acoustic technique for measuring the enhancement, Aerosol Sci. Tech., 43, 1006-1012, doi:10.1080/02786820903117932, 2009.

Marley, N. A., Gaffney, J. S., Castro, T., Salcido, A., and Frederick, J.: Measurements of aerosol absorption and scattering in the Mexico City Metropolitan Area during the MILAGRO field campaign: a comparison of results from the T0 and T1 sites, Atmos. Chem. Phys., 9, 189-206, doi:10.5194/acp-9-189-2009, 2009.

Moosmüller, H., Chakrabarty, R. K., and Arnott, W. P.: Aerosol light absorption and its measurement: A re- view, J. Quant. Spectrosc. Rad. Trans., 110(11), 844-878, doi:10.1016/j.jqsrt.2009.02.035, 2009.

Moosmüller, H., Chakrabarty, R. K., Ehlers, K. M., and Arnott, W. P.: Absorption Ångström coefficient, brown carbon, and aerosols: basic concepts, bulk matter, and spherical particles, Atmos. Chem. Phys., 11, 1217-1225, doi:10.5194/acp-11-12172011, 2011a.

Moosmüller, H., and Chakrabarty, R. K.: Technical Note: Simple analytical relationships between Ångström coefficients of aerosol extinction, scattering, absorption, and single scattering albedo, Atmos. Chem. Phys. Discuss., 11, 19213-19222, doi:10.5194/acpd-11-19213-2011, 2011 b.

Müller, T., Henzing, J. S., de Leeuw, G., Wiedensohler, A., Alastuey, A., Angelov, H., Bizjak, M., Collaud Coen, M., Engström, J. E., Gruening, C., Hillamo, R., Hoffer, A., Imre, K., Ivanow, P., Jennings, G., Sun, J. Y., Kalivitis, N., Karlsson, H., Komppula, M., Laj, P., Li, S.-M., Lunder, C., Marinoni, A., Martins dos Santos, S., Moerman, M., Nowak, A., Ogren, J. A., Petzold, A., Pichon, J. M., Rodriquez, S., Sharma, S., Sheridn, P. J., Teinilä, K., Tuch, T., Viana, M., Virkkula, A., Weingartner, E., Wilhelm, R., and Wang, Y. Q.: Characterization and intercomparison of aerosol absorption photometers: result of two intercomparison workshops, Atmos. Meas. Tech., 4, 245-268, doi:10.5194/amt-4-245-2011, 2011.

Nakayama, T., Kondo, Y., Moteki, N., Sahu, L. K., Kinase, T., Kita, K., and Matsumi, Y.: Size-dependent correction factors for absorption measurements using filter-based photometers: PSAP and COSMOS, J. Aerosol Sci., 41, 333-343, 2010.

Procopio, A. S., Remer, L. A., Artaxo, P., Kaufman, Y. J., and Holben, B. N.: Modeled spectral optical properties for smoke aerosols in Amazonia, Geophys. Res. Lett., 30(24), 2265, doi:10.1029/2003GL018063, 2003.

Procopio, A. S., Artaxo, P., Kaufman, Y. J, Remer, L. A., Schafer, J. S., and Holben, B. N.: Multiyear analysis of Amazonian biomass burning smoke radiative forcing of climate, Geophys. Res. Lett., 31, L03108, doi:10.1029/2003GL018646, 2004.

Ramanathan, V. and Carmichael, G.: Global and regional climate changes due to black carbon, Nat. Geosci., 1, 221-227, 2008.

Reid, J. S., Hobbs, P. V., Ferek, R. J., Blake, D. R., Martins, J. V., Dunlap, M. R., and Liousse C.: Physical, chemical and optical properties of regional hazes dominated by smoke in Brazil, J. Geophys. Res., 103, 32059-32080, 1998.

Rissler, J., Vestin, A., Swietlicki, E., Fisch, G., Zhou, J., Artaxo, P., and Andreae, M. O.: Size distribution and hygroscopic properties of aerosol particles from dry-season biomass burning in Amazonia, Atmos. Chem. Phys., 6, 471-491, doi:10.5194/acp6-471-2006, 2006.

Rizzo, L.V., Artaxo, P., Karl, T., Guenther, A. B., and Greenberg, J.: Aerosol properties, in-canopy gradients, turbulent fluxes and VOC concentrations at a pristine forest site in Amazonia, Atmos. Environ., 44, 503-511, 2010.

Schmid, H., Laskus, L., Abraham, H. J., Baltensperger, U., Lavanchy, V., Bizjak, M., Burba, P., Cachier, H., Crow, D., Chow, J., Gnauk, T., Even, A., Brink, H. M., Giesen, K.-P., Hitzenberger, R., Hueglin, C., Maenhaut, W., Pio, C., Carvalho, A., Putaud, J.-P., Toom-Sauntry, D., and Puxbaum, H.: Results of the "carbon conference" international aerosol carbon round robin test stage I, Atmos. Env., 35(12), 2111-2121, doi:10.1016/S1352-2310(00)00493-3, 2001. 
Schmid, O., Artaxo, P., Arnott, W. P., Chand, D., Gatti, L. V., Frank, G. P., Hoffer, A., Schnaiter, M., and Andreae, M. O.: Spectral light absorption by ambient aerosols influenced by biomass burning in the Amazon Basin. I: Comparison and field calibration of absorption measurement techniques, Atmos. Chem. Phys., 6, 3443-3462, doi:10.5194/acp-6-3443-2006, 2006.

Schnaiter, M., Horvath, H., Möhler, O., Naumann, K. H., Saathoff, H., and Schöck, O. W.: UV-VIS-NIR spectral optical properties of soot and soot-containing aerosols, J. Aerosol Sci., 34, 14211444, 2003.

Schuster, G. L., Dubovick, O., and Holben, B. N.: Ångström exponent and bimodal aerosol size distributions, J. Geophys. Res., 111, D07207, doi:10.1029/2005/JD006328, 2006.

Sun, H., Biedermann, L., and Bond, T. C.: Color of brown carbon: A model for ultraviolet and visible light absorption by organic carbon aerosol, Geophys. Res. Lett., 34, L17813, doi:10.1029/2007GL029797, 2007.
Weingartner, E., Saathoff, H., Schnaiter, M., Streit, N., Bitnar, B., and Baltensperger, U.: Absorption of light by soot particles: Determination of the absorption coefficient by means of aethalometers, J. Aerosol Sci., 34, 1445-1463, 2003.

Yu, H., Kaufman, Y. J., Chin, M., Feingold, G., Remer, L. A., Anderson, T. L., Balkanski, Y., Bellouin, N., Boucher, O., Christopher, S., DeCola, P., Kahn, R., Koch, D., Loeb, N., Reddy, M. S., Schulz, M., Takemura, T., and Zhou, M.: A review of measurement-based assessments of the aerosol direct radiative effect and forcing, Atmos. Chem. Phys., 6, 613-666, 2006, http://www.atmos-chem-phys.net/6/613/2006/. 